\title{
PARADIGMA ANTROPOSENTRIS DALAM MEMAHAMI HADIS-HADIS MUAMALAH
}

\section{Salamah Noorhidayati}

Institut Agama Islam Negeri Tulungagung e-mail: salamahnoorhidayati@gmail.com

\begin{abstract}
In this contents, Hadith reflects the different teaching of Islam, including creed, worship, and muamalah. All of that requires a different treatment and understanding the proportionally. This article examines how to understand the Hadiths in the field of muamalah and what is the paradigm construct of it. By using the method of subjective-humanistic hermeneutics, this article produces findings, as follows: first, the Hadiths of muamalah reflect construct of human relationships and it can change according to the changes and development of social life. Therefore, these Hadiths can be understood by using the anthropocentric paradigm, oriented on the needs of humans and make it as a subject and object either of the understanding. Second, this anthropocentric paradigm aims to find the sunnah and host it again in the present day. This anthropocentric understanding holds on to the principles and the universal values contained in the text of the Hadith as well as humanistic social ethics that upholds human values that are fairness, equal and tolerant without discrimination in various fields.
\end{abstract}

\begin{abstract}
Abstrak: Dari segi kandungannya, hadis Nabi mencerminkan muatan ajaran tentang akidah, ibadah dan muamalah. Kesemuanya itu membutuhkan pensikapan yang berbeda dan pemahaman yang proporsional. Artikel ini mengkaji bagaimana memahami hadis-hadis Nabi dalam bidang muamalah serta bagaimana konstruksi paradigma yang dimaksud. Dengan menggunakan metode hermeneutika subjektif-humanistik, artikel ini menghasilkan temuan, sebagai berikut: Pertama, hadis muamalah merefleksikan konstruk relasi manusia, dan bisa berubah sesuai dengan perubahan dan perkembangan kehidupan sosial. Oleh karena itu hadis-hadis ini bisa dipahami dengan menggunakan paradigma antroposentris, yang berorientasi pada kebutuhan manusia dan menjadikannya sebagai subjek sekaligus objek dalam pemahaman. Kedua, paradigma antroposentris ini bertujuan untuk menemukan sunnah Nabi dan menghadirkannya kembali dalam konteks sekarang. Pemahaman antroposentris ini berpegang pada prinsip dan nilai-nilai universal yang terkandung dalam teks hadis serta etika sosial humanistik yang menjunjung tinggi nilai kemanusiaan yang berkeadilan, setara dan toleran tanpa diskriminasi dalam berbagai bidang.
\end{abstract}

Keywords: antroposentris; muamalah; paradigma; pemahaman hadis

\section{A. Pendahuluan}

Secara umum, studi hadis dapat dipetakan menjadi dua. Pertama, kajian tentang otentisitas hadis yang memfokuskan pada kaidah kesahihan hadis, baik 
secara teoritis konseptual maupun implementasi praktis. Kedua, kajian tentang pemahaman hadis. Dua tipologi ini bisa dilihat dari karya beberapa tokoh yang mewakili zamannya. Dalam sejarah perkembangannya kajian terkait dengan yang pertama sangat dominan. Sebagai representasi dari ulama masa klasik ${ }^{1}$ yaitu al-ḥākim al-Naisābūrī (w. 405H), al-Khātib al-Baghdādī (w. 463H); ulama masa pertengahan ${ }^{2}$ yaitu Ibn al-Șalạ̣ (w. 643 H), al-Nawawī (w.676 H), al'Asqalānī(w. 852 H) dan al-Suyuṭī (w. 911 H); masa modern³ seperti Șubḥi alȘālih, 'Ajjaj 'al-Khatib, al-Ṭahhan, al-A'ẓamiy, al-Siba'ĩ dan masa kontemporer4 seperti al-Damīniy, Țāhir Al-Jawābiy, al- Adlabī Abū Rayyah. Dengan redaksi dan urutan yang berbeda-beda, kitab-kitab karya mereka secara umum membahas tentang kriteria kesahihan hadis, baik sanad maupun matan.

Sementara karya yang menawarkan tentang rumusan teoritis maupun aplikasi pemahaman hadis belum banyak ditemukan. Karya-karya awal dalam bidang pemahaman hadis yang muncul berupa sharh hadis dengan kecenderungan pola taḥlìlī atau ijmālī dan bersifat tekstual. Sedangkan tawaran pemahaman kontekstual baru muncul pada masa belakangan dengan tokoh alQaraḍawi dan al-Gazāli. Untuk Indonesia, dikenal juga beberapa nama seperti Syuhudi Ismail, Nizar Ali dan Ali Mustafa Ya'qub. ${ }^{5}$ Buku-buku ini cukup informatif dalam hal variasi metodologi pemahaman hadis dilengkapi dengan beberapa contoh pemahaman.

Berdasarkan kedua pola ini, ditemukan beberapa problema dalam pengkajian hadis. Pertama, bahwa kajian hadis lebih sering mengedepankan aspek otentisitas hadis baik melalui upaya kritik sanad (al-naqd al-khārijī/kritik ekstern) maupun kritik matan (al-naqd al-dākhilī/ kritik intern) yang bermuara

\footnotetext{
1Muhammad Dede Rudliyana, Perkembangan Pemikiran Ulum al-Hadis dari Klasik sampai Modern (Bandung: Pustaka Setia, 2003), h. 36-59.

${ }^{2}$ Rudliyana, Perkembangan Pemikiran, h. 63-99.

3Ibid., h. 101-114.

4 Tokoh-tokoh yang termasuk masa kontemporer adalah mereka yang menyajikan karyanya secara kritis, baik itu terkait dengan kritik sanad, maupun matan.

${ }^{5}$ Muhammad al-Gazālī, al-Sunnah al-Nabawiyyah bain ahl al-Fiqh wa Ahl al-Hadīth, (Kairo: Dār al-Syurūq, 1996). Yusuf al-Qaraḍawi, Kaifa Nata’amal Ma'a al-Sunnah, (Kairo: Dār al-Syurūq, 1992). Syuhudi Isma'il, Hadis Nabi Yang Tekstual dan Kontekstual: Telaah Ma'anil Hadis Tentang Ajaran Islam Yang Universal, Temporal dan Lokal (Jakarta: Bulan Bintang, 1994), Nizar Ali, Memahami Hadis Nabi (Metode dan Pendekatan). Yogyakarta: CESaD YPI al-Rahmah, 2001). Ali, Hadis Versus Sains Memahami Hadis-hadis Musykil, (Yogyakarta: Teras, 2008).
} 
pada kualitas șahịḥ atau darîf. Sementara untuk kajian pemahaman hadis, baru muncul pada beberapa dekade terakhir. Kedua, problem Ketidakimbangan kajian antara otentisitas dan pemahaman ini menimbulkan problem baru. Yaitu, hasil kajian otentisitas hadis tidak berbanding lurus dengan kajian pemahaman hadis. Suatu hadis, bisa dinyatakan șaḥịh (benar) dalam konteks munculnya, namun ternyata dirasa tidak șālih (sesuai) untuk diterapkan dalam konteks sekarang dalam ruang dan waktu yang berbeda.

Jika ditelisik lebih lanjut, problem ini muncul sebagai implikasi terjadinya generalisasi pemahaman hadis tanpa melihat segi struktur, model periwayatan, bidang materi atau sifat hadis. Pendekatan kajian yang digunakan juga turut berkontribusi dalam hal ini. Di mana pendekatan tekstualis mewarnai kajian literatur masa klasik sampai modern sebagaimana ditemukan dalam kitab sharh hadis, dan baru belakangan marak pemahaman secara kontekstual.

Sebagaimana diketahui, dari materi yang dikandung, hadis Nabi bisa dipilah menjadi hadis yang syar'iyyah dan ghair syar'iyyah, atau akidah, ibadah/syari'ah dan muamalah. Pemilahan ini tentunya berimplikasi pada sifat ajaran dan pengamalannya. Hadis-hadis terkait bidang muamalah mencerminkan entitas yang berbeda dengan hadis-hadis tentang akidah dan syari'ah. Hadis tentang akidah dan syari'ah cenderung bersifat doktriner, sedangkan hadis mu'amalah, sebagai proyeksi relasi antar manusia yang dinamis dan konstruksinya bersifat kontekstual. Mengabaikan sisi ini membawa dampak pada pemahaman yang kontradiktif antara hadis nabi dengan perkembangan realitas kekinian.

Pada era kontemporer, pemahaman terhadap suatu hadis tertentu seringkali menimbulkan suatu masalah dalam kehidupan bermasyarakat. Misalnya hadis tentang relasi antar umat beragama yang menunjukkan perintah memerangi dan membunuh Yahudi dan Nasrani, larangan meniru dan menyerupainya serta larangan memulai mengucapkan salam kepada mereka, dan lainlain. Mengamalkan hadis-hadis tersebut untuk umat Islam yang hidup dalam masyarakat yang majemuk, seperti di Indonesia, akan menimbulkan problem besar. Sikap progresif seperti yang tercermin dalam hadis di atas kalau dipegangi secara tekstual akan melahirkan sikap keberagamaan yang eksklusif, kaku dan diskriminatif yang berdampak negatif bagi hubungan sosial antar umat beragama.

Demikian juga dengan hadis-hadis tentang relasi gender. Secara tekstual, ada beberapa hadis yang menunjukkan pembatasan kiprah dan peran per- 
empuan di ruang publik. Misalnya larangan perempuan bepergian tanpa muhrim, larangan ber-ikhtilat dengan lelaki dalam suatu forum, larangan melaksanakan salat berjama'ah di masjid. Pembatasan tersebut tidak hanya terjadi di wilayah domestik, namun juga privat dalam konteks relasi suami istri. Misalnya hadis yang menyatakan ketaatan mutlak seorang istri pada suaminya dalam hal menjalankan ibadah dan hubungan seksual.

Walaupun hadis-hadis tersebut dinilai sahih (șạ̣ịh al-isnād wa al-matn), namun pengamalannya untuk konteks-konteks tertentu memunculkan sikap diskriminatif karena bertentangan dengan nilai-nilai dasar kemanusiaan ( fundamental values) dan Hak Asasi Manusia. Pertentangannya inilah yang menjadikan hadis yang sahih menjadi tidak salih (tidak relevan), kecuali dibaca dan dipahami dengan pendekatan dan paradigma baru.

Studi hadis sebagai salah satu bagian dari ilmu pengetahuan tidak boleh bersifat statis dan stagnan. Ia harus bisa dimodifikasi dan diadaptasikan dengan perubahan dan perkembangan zaman. Untuk itulah, perubahan dan pergeseran paradigma (shifting paradigm) menjadi suatu keniscayaan dalam rangka memahami fenomena empirik dan realitas sosial. Pergeseran paradigma ini tidak perlu disikapi sebagai suatu gerakan dekonstruktif, tapi sebaliknya harus disikapi sebagai suatu upaya penyempurnaan terhadap konstruk epistemologi keilmuan yang mencerminkan semangat zamannya, ${ }^{6}$ dan dalam rangka menghidupkan kembali sunnah Nabi yang șāliḥ li kulli zamān wa makān. ${ }^{7}$

Berdasarkan paparan di atas, maka masalah pokok yang menjadi fokus pembahasan dalam artikel ini adalah bagaimana paradigma pemahaman hadis Nabi dalam bidang muamalah, khususnya terkait relasi umat beragama dan

6M. Amin Abdullah, Studi Agama: Normativitas dan Historisitas? (Yogyakarta: Pustaka Pelajar, 1996), h. 309; lihat juga Suryadi, "Rekonstruksi Kritik Sanad dan Matan dalam Studi Hadis" dalam ESENSIA Jurnal Ilmu-Ilmu Ushuluddin, Vol. 16, No. 2, Oktober 2015, h. 178.

${ }^{7}$ Slogan ini oleh kelompok tertentu seringkali diartikan secara tekstualis, dan dijadikan argumen bagi penolakan atas kelompok lain yang berusaha melakukan interpretasi dan kontekstualisasi terhadap teks-teks keagamaan dengan alasan bahwa ajaran Islam sudah șālih (relevan) untuk waktu dan tempat, dimanapun dan kapanpun. Keyakinan seperti ini akan menyebabkan umat Islam terjebak pada problem otentisitas teks dan oleh karenanya upaya kontekstualisas dengan mempertimbangkan sisi historisitas teks, dianggap menyalahi dan menyelewengkan ajaran Islam. "Kesalihan" yang penulis ajukan disini justru bertentangan dengan pemahaman konvensional seperti di atas dan sekaligus ingin membantah bahwa ajaran Islam (yang terumuskan dalam teks keagamaan) yang ada tanpa upaya kontekstualisasi tak berbeda dengan sebuah dokumen yang masuk museum, mati, dan tidak bisa berbicara kepada dunia kontemporer untuk menyelesaikan problem-problem yang dihadapi. 
gender, yang relevan (șālih) dengan perkembangan zaman. Adapun jika dirinci, maka masalah ini bisa dirumuskan dalam beberapa pertanyaan: 1) Bagaimana memahami hadis-hadis tentang relasi umat beragama dan gender?; 2) Bagaimana konstruk paradigma tersebut dalam memahami hadis Nabi tentang relasi umat beragama dan gender?

Sesuai dengan rumusan masalah yang dikemukakan, maka artikel ini bertujuan: 1) menawarkan bentuk paradigma baru yang digunakan dalam memahami hadis-hadis tentang relasi umat beragama dan gender, dan 2) mendeskripsikan bangunan paradigma yang dimaksud mencakup prinsipprinsip yang menjadi acuan dalam memahami hadis-hadis tentang relasi umat beragama dan gender serta kriteria yang bisa dijadikan parameter kesalihannya.

Adapun manfaat dari artikel ini adalah untuk memberikan solusi terhadap implementasi kaidah kesahihan sanad dan matan yang dianggap problematik sekaligus menawarkan suatu metode praktis dalam menyikapi suatu hadis yang ada dalam kitab koleksi hadis yang ada, terutama berkaitan dengan hadis- hadis tentang relasi umat manusia.

\section{B. Potret Muamalah dalam Hadis Nabi}

Dalam sejarah hidupnya, Nabi mempunyai multi peran. Al-Qarafi, mengidentifikasi berbagai peran yang disandang oleh Nabi saw, yaitu sebagai Nabi dan Rasul penyampai risalah, kepala negara, pemimpin masyarakat, panglima perang, hakim, mufti, suami dan pribadi. ${ }^{8}$ Pengetahuan dan pengakuan akan peran Nabi sebagai penyampai risalah Ilahiyah sekaligus kesadaran akan sisi manusiawinya mempunyai manfaat yang besar dan mampu mengarahkan kepada pemahaman hadis secara utuh. ${ }^{9}$ Pemilahan ini juga memberikan pengaruh yang berbeda terhadap keumuman hukum dan kekhususannya ('ämkhāș), mengikat tidaknya (muțlāq-muqayyad) serta sisi universalitas dan lokalitas nilai yang dikandungnya. ${ }^{10}$

${ }^{8} \mathrm{Abu}$ al-Abbas Ahmad ibn Idris al-Qarafi, Al-Furūq fi Anwā' al-Furūq, juz I, kaedah ke-36 (Beirut: Dar al-Kutub al-'Ilmiyyah, 1998), h. 357; W. Montgomery Watt, Muhammad Prophet and Statesman (London: Oxford University Press, 1996), lihat juga Isma'il, Hadis Nabi yang Tekstual, h. 33-34 dan Philip K Hitti, History of the Arabs (London: The Macmillan Press, 1974), h. 139.

${ }^{9}$ Mahmud Syalțut, al-Islām 'Aqīdah wa Sharīah, (Kairo: Dār al-Qalam, 1966), h. 510.

${ }^{10}$ al-Qarafi, Al-Furūq, h. 357. 
Hadis-hadis Nabi merupakan cerminan hidup Nabi dan kehidupannya bersama generasi Muslim awal. Tentunya jika ditelusuri akan tergambar berbagai persoalan yang muncul dan dialami sendiri oleh Nabi maupun para sahabatnya, baik terkait dengan kehidupan beragama maupun bermasyarakat. Sunnah Nabi kadang merupakan aksi kreatif Nabi dalam tugasnya sebagai Rasul yang ingin menyampaikan ajaran Islam, namun kadang juga merupakan reaksi dan tanggapan atas persoalan yang dihadapi umat Islam. Hadis Nabi mengikuti irama dan dinamika masyarakat, maka bahasa dan materinya merupakan cerminan proses interaksi antara Nabi dan umatnya saat itu. ${ }^{11}$

Dalam Islam, proses interaksi ini membentuk tiga arah, yaitu hạbl min Allāh (hubungan manusia dengan Tuhannya), habl min al-nās (hubungan sesama manusia), dan habl min al-bỉah (hubungan kepada alam semesta). Ketiga hubungan ini harus seimbang dan bersinergi. Artinya, tidak boleh memfokuskan dan mengutamakan pada satu bentuk hubungan saja. Hubungan kepada Allah dari sudut sosiologi disebut dengan hubungan vertikal dan hubungan sesama manusia (dan alam) disebut hubungan horizontal. Pola yang kedua inilah yang selaras dengan konsep interaksi sosial atau dalam bahasa agama disebut mu'āmalah.

Kata "mu'āmalah" bisa berarti perlakuan, prosedur, relasi sosial, kehidupan sosial, hubungan satu sama lain, interaksi sosial, sikap dan tindakan terhadap orang lain, bisnis dan transaksi. ${ }^{12}$ Dalam konteks artikel ini, "muamalah" menunjuk arti interaksi sosial, yaitu hubungan dinamis yang saling mempengaruhi satu sama lain, baik dalam hubungannya antara individu dengan individu, individu dengan kelompok, dan kelompok dengan kelompok ${ }^{13}$ Proses interaksi ini menjadi suatu keniscayaan dikarenakan adanya kepentingan atau kebutuhan sesuatu, keinginan bersosialisasi dan bekerjasama dengan komunitas lain di luar dirinya. Proses Interaksi yang berlangsung dalam masyarakat tidak mungkin menunjukkan wajah tunggal. Ada dinamika, pasang surut, naik turun, damai konflik dan lain-lain. Atau, dalam istilah Soerjono Soekanto disebut proses asosiatif dan proses disosiatif. ${ }^{14}$

\footnotetext{
${ }^{11}$ Salamah Noorhidayati, "Paradigma Pemahaman Hadis: Dari Kesahihan Menuju Kesalihan Hadis" Laporan Penelitian Individual, IAIN Tulungagung, 2015, h. 62.

${ }^{12}$ Lihat Hans Wehr, A Dictionary of Modern Written Arabic, J. Milton Cowan (ed) (London: Weisbaden Otto Harrassowitz, 1971), h. 646.

${ }^{13}$ Noorhidayati, "Paradigma”, h. 71.

${ }^{14}$ Proses asosiatif adalah bentuk interaksi sosial yang dapat meningkatkan hubungan solidaritas antara individu. Proses ini bisa berbentuk: 1) Kerja sama (cooperation); akomodasi
} 
Mengacu pada macam-macam interaksi sosial sebagaimana deskripsi terdahulu, maka interaksi umat Islam dengan lainnya bisa membentuk 3 pola: a) interaksi antara individu Muslim dengan Muslim lain, b) interaksi antara Muslim dengan non-Muslim baik secara individu maupun kelompok, dan c) interaksi antara komunitas Muslim dengan komunitas non-Muslim. ${ }^{15}$ Sementara dilihat dari jenis pelakunya, maka 3 pola interaksi di atas mengarah pada dua bentuk. Pertama, yaitu hubungan manusia berdasarkan jenis agama, Muslim-Muslim, Muslim-non-Muslim, baik dalam lingkungan keluarga (orangtua-anak), maupun masyarakat. Kedua, hubungan berdasar jenis kelamin atau relasi gender, lakilaki-perempuan, baik dalam keluarga (suami-istri, ibu-anak) maupun masyarakat. Dilihat dari sifatnya, kedua bentuk interaksi ini bisa dikategorikan menjadi bersifat apresiatif dan kritis. Sikap apresiatif, mengarah pada bentuk interaksi asosiatif, sementara kritis mengarah pada bentuk interaksi disosiatif.16

Berikut ini ada beberapa hadis yang menunjukkan pada bentuk interaksi dilihat dari jenis pelakunya; antar agama dan gender baik yang bersifat apresiatif maupun kritis, ${ }^{17}$ yang selama ini seringkali memicu sikap dan tindakan disharmoni dalam masyarakat.

\section{Hadis-hadis tentang Relasi Umat Beragama}

Penelusuran terhadap hadis Nabi tentang hubungan umat Islam dengan pemeluk agama lain menunjukkan bahwa ada dua sikap hadis terhadap komunitas non-Muslim: apresiatif dan kritis. Sikap apresiatif terhadap nonMuslim terlihat misalnya pada beberapa hal berikut: anjuran mendakwah Islam secara damai kepada Ahli Kitab, ahl al-kitab boleh memasuki masjid sebagai

(accomodation) dan Asimilasi. Sementara Proses disosiatif adalah bentuk interaksi sosial yang dapat merenggangkan hubungan solidaritas antar individu meliputi persaingan, kontravensi, dan konflik. Baca Selo Soemardjan dan Soelaeman Someardi, Setangakai Bunga Sosiologi Jakarta: Yayasan Badan Penerbit Fakultas Ekonomi Universitas Indonesia, 1964), h. 177.

${ }^{15}$ Noorhidayati, “Paradigma”, h. 72.

16Ibid., h. 72-73.

${ }^{17}$ Istilah "apresiatif" dipilih untuk menunjukkan pada hadis-hadis yang memberi kesan positif terhadap relasi dalam Islam, baik relasi umat Islam dengan lainnya maupun relasi gender ; sementara "kritis" untuk menunjukkan pada hadis-hadis yang memberi kesan negatif terhadap relasi tersebut. Untuk hadis-hadis tentang relasi umat beragama, bisa dilihat pada Noorhidayati, Hadis-Hadis Diskriminatif terhadap Umat Beragama Lain (Pemahaman Hadis dengan Pendekatan Sosio-Historis), (Tulungagung: STAIN Tulungagung Press, 2010), h. 62. Istilah ini juga digunakan dalam Noorhidayati, "Menalar Pandangan Hadis-hadis tentang Perempuan", Disertasi, Yogyakarta: Program Pascasarjana UIN Sunan Kalijaga, 2013. 
tempat ibadah kaum Muslim,18 penghormatan Nabi terhadap jenazah orang Yahudi, perintah menjawab salam ahl al-kitab, menjalin hubungan baik Nabi dengan komunitas Yahudi. ${ }^{19}$

Sementara sikap kritis-konfrontatif terhadap non-Muslim terlihat antara lain dalam teks-teks hadis yang menyatakan larangan meniru Yahudi dan asrani, 20 larangan menikahi wanita Yahudi dan Nasrani, ${ }^{21}$ larangan menyampaikan salam kepada ahl al-kitab, ${ }^{22}$ perintah membunuh orang Yahudi, dan lain-lain ${ }^{23}$

\section{Hadis-Hadis tentang Relasi Gender}

Sejalan dengan hadis-hadis tentang hubungan antar agama, hadis yang membicarakan tentang relasi gender juga ada yang bersifat apresiatif dan sebagian besar bersifat kritis. ${ }^{24}$ Sikap apresiatif misalnya ditunjukkan oleh hadis tentang persamaan antara laki-laki dan perempuan sebagai pemimpin dan dimintai pertanggungjawaban atas yang dipimpin. Sementara sikap kritis terhadap relasi gender ini sangat banyak, misalnya di antaranya adalah perempuan boleh dipoligami, istri yang tidak memenuhi keinginan seksual suami akan dilaknat, negara yang dipimpin perempuan tidak akan jaya.

\section{Konstruk Paradigma Antroposentris}

Sebagaimana gambaran tentang gerak dinamis kehidupan Nabi bersama para generasi Muslim awal, hadis-hadis bidang muamalah lebih bersifat situasional dan temporal. Untuk itu diperlukan model pemahaman yang berbeda dengan hadis ibadah dan akidah. Pemahaman dengan menggunakan

18Ibn Qayyim al-Jawziyyah, Zād al-Ma'ād, III, (t.t.p.: Dār Ihyā al-Turath al-'Arabiy, t.th.), h. 49.

${ }^{19}$ al-Bukhari, Șahịh al-Bukhāri I, (Singapore: Sulaiman Ma'i, t.th.), h. 186, Lihat juga Muslim, Șahịh Muslim I, (t.t.p: Dār al-Fikr, t.th.), h. 136.

${ }^{20}$ Muhammad bin Ismā'îl Abū 'Abdillah al-Bukhārī, al-Jāmi' al-Șahịh al-Mukhtașar, tahqiq. Muṣțafā Dīb al-Bigā, (Beirut: Dār Ibnu Kathīr, 1987), Juz 3, h. 1274.

${ }^{21}$ Ibid., Juz 5, h. 2024.

${ }^{22}$ Muslim bin al-Ḥajjāij Abū al-Ḥasan al-Qushairī al-Naisābūrī, Ṣahịḥ Muslim, taḥīi. Muhammad Fu'ād 'Abd al-Bāqī (Beirut: Dār Ihyyā' al-Turāth al-'Arabī, t.th), Juz 4, h. 1705. Lihat juga alBukhārī, al-Jāmi' al-Șahịh, Juz 3, h. 1703.

23al-Bukhārī, al-Jāmi' al-Șahịh, Juz 2, h. 774 dan 775.

${ }^{24}$ Noorhidayati, “Menalar”, h. 133. 
paradigma antroposentries ${ }^{25}$ dan pendekatan kontekstual dianggap lebih tepat untuk bisa mengungkap makna sebenarnya.

Paradigma ini diarahkan pada upaya fungsionalisasi hadis yang lebih bersifat pragmatis dan berorientasi pada kebutuhan manusia sekarang. Paradigma antroposentries ini memposisikan manusia sebagai subjek dan objek sekaligus. Sebagai subjek, manusia diberi ruang yang luas dan bebas untuk membaca dan memahami teks; dan selanjutnya hasil pembacaan dan pemanfaatannya juga diorientasikan untuk kepentingan manusia.

Ada dua argumen yang bisa diajukan untuk mendukung paradigma tersebut. Pertama, refungsionalisasi hadis. Hadis yang sudah terkodifikasikan dalam sebuah kitab merupakan hasil dari suatu proses yang panjang dari proses transmisi sunnah aktual Nabi (sunnah qauliyah, filiyah, taqrīriyah dan ahwāal Nabi) menjadi teks terkodifikasi. Dalam hal ini, sunnah Nabi berbeda dengan hadis Nabi. "Sunnah" dipahami sebagai suatu konsep yang bersifat fungsionaldinamis, sementara "hadis" dipahami sebagai suatu konsep yang bersifat struktural-statis. Dengan kata lain, sunnah dalam aktualisasi praktisnya dipahami secara fleksibel, tidak kaku; sementara hadis dipahami sebagai sesuatu yang sudah baku dan tidak dapat dirubah lagi. Oleh karena itu, paradigma memahami hadis harus bisa mengembalikan fungsi hadis sebagai media untuk mengetahui sunnah sehingga hadis Nabi lebih bisa menggambarkan sunnah yang hidup. ${ }^{26}$ Mengingat hadis-hadis muamalah adalah hadis-hadis yang bersifat relatif, dinamis dan menggambarkan struktur interaksi Muslim dalam masyarakat. maka membangun paradigma pemahaman hadis yang mengembalikan hadis pada fungsinya semula menjadi urgen. 27

Kedua, reorientasi studi hadis. Sampai saat ini, untuk bisa mengamalkan hadis, kita dituntut untuk mengetahui otentisitas dan kualitas melalui penelitian berdasarkan kaidah kesahihan hadis. Penerapan kaidah kesahihan hadis dalam

${ }^{25}$ Paradigma antroposentris adalah cara pandang yang digunakan dalam memahami hadis secara kontekstual yang berorientasi pada manusia, baik sebagai subjek maupun objek. Istilah ini, dalam buku yang lain saya sebut sebagai human centries, yang berpusat pada manusia. Lihat Noorhidayati, "Paradigma”, h. 105-106.

${ }^{26}$ Noorhidayati, “Paradigma”, h. 98. Brown, Daniel W., Menyoal Relevansi Sunnah Dalam Islam Modern (Bandung: Mizan, 2000). Musahadi, HAM. Evolusi Konsep Sunnah; Implikasinya pada Perkembangan Hukum Islam, (Semarang: Aneka Ilmu bekerja sama dengan IAIN Walisongo Press, 2000).

${ }^{27}$ Noorhidayati, “Paradigma”, h. 99. 
proses penelitian selama ini, baik dalam kritik sanad maupun kritik matan hadis dalam taraf tertentu menunjukkan problem. yang memunculkan pandangan yang kontradiktif. Di satu sisi, untuk memperoleh hadis yang șạīh, ditempuh dua jalan, yaitu penelitian terhadap sanad dan matan sekaligus. Namun di sisi lain, banyak hadis yang tidak sejalan antara kualitas sanad dan kualitas matannya.

Walaupun langkah metodologis penelitian sanad telah dibakukan, namun hal itu masih menyisakan ruang kontroversi hasil yang ditemukan, bahkan penelitian sanad ini pun masih mengandung problem. Kajian hadis dengan mengedepankan penelitian terhadap sanad melalui penelusuran biografi periwayat dirasa terlalu menyita waktu dan menguras energi dan pikiran. Sementara hasil penelitian antara peneliti yang satu dengan yang lain tidak sedikit yang berbeda bahkan menunjukkan hasil yang kontradiktif. Karena tolak ukur yang dipakai oleh para kritikus hadis berbeda-beda, maka sebagian menganggap sahih, sebagian menganggap dânff. Padahal, dalam kondisi sanad lemah, menurut kaidah yang ada, penelitian terhadap matan hadis tidak perlu dilanjutkan. Namun anehnya, dalam kasus tertentu hadis-hadis yang dha'if masih tetap diamalkan. Di sisi lain ditemukan adanya hadis yang sanadnya disepakati bernilai sahih tapi matannya mengandung kelemahan. Ini menunjukkan bahwa kualitas matan tidak selalu sejalan dengan kualitas sanadnya ${ }^{28}$

Oleh karena itu, adanya shifting paradigm dalam berinteraksi dengan hadis menjadi signifikan. Kajian hadis semestinya tidak hanya berhenti pada uji otentisitas (maqbūl atau mardūd) yang berorientasi pada aspek kualitas (șahīḥ,

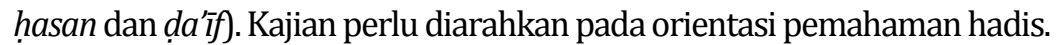

Paradigma pemahaman hadis bidang muamalah yang bersifat antroposentries-kontekstual ${ }^{29}$ layak dipertimbangkan. Manusia, sebagai subjek pemahaman, berhak menggali nilai-nilai substansial dari sebuah teks dengan mempertimbangkan sisi- sisi manfaat dan relevansi nilai yang dikandung.

28'Terkait dengan problematika penelitian hadis, lihat Ibid., h. 103-105.

${ }^{29}$ Pendekatan antroposentris-kontekstual dalam memahami hadis-hadis muamalah adalah suatu pendekatan yang berorientasi pada manusia, baik sebagai subjek maupun objek. Sebagai subjek manusia mempunyai ruang yang kebebasan dalam memahami teks, dan sebagai hasil pemahamannya harus diorientasikan untuk kemaslahatan umat manusia (objek). Kontekstual, adalah cara baca terhadap teks hadis dengan tidak terpaku pada bunyi literalnya. Manusia sebagai reader, dengan menggunakan berbagai pertimbangan di luar teks hadis akan mampu mendapatkan pemahaman yang kontekstual Dikatakan kontekstual, karena disarikan berdasarkan pengetahuannya terhadap konteks lahirnya hadis dan konteks di mana hadis akan diterapkan. Karena pemahaman yang dihasilkan sesuai dengan konteks kekinian, maka pemahamannya bersifat salih (relevan). Bacajuga pernyataan di awal sub bab ini dan footnote 37. 
Dengan paradigma ini diharapkan hadis-hadis yang berkualitas șaḥịh tetap șāliḥ dan bisa diamalkan (ma'mūl bih).30

\section{Prinsip-Prinsip yang Menjadi Acuan dalam Memahami Hadis- Hadis Bidang Muamalah}

Paradigma antroposentris memberikan ruang subjektifitas yang luas bagi manusia. Untuk menghindari terjadinya pemahaman "yang kebablasan" diperlukan prinsip yang bisa dijadikan guidance. Mengingat posisi hadis sebagai sumber ajaran kedua, maka untuk menemukan pemahaman yang șāliḥ sesuai dengan sunnah Nabi, hadis Nabi harus dipahami dalam sinaran al-Qur'an. Oleh karena itu, pemahaman hadis harus berpegang pada dua hal:

\section{Nilai-nilai Universal yang Terkandung dalam Teks Hadis}

Nilai-nilai universal yang dimaksud adalah mengacu pada semangat alQur'an, yaitu semangat keimanan universal (monoteisme), semangat egalitarianism (kesetaraan), semangat kebebasan/kemerdekaan, dan semangat keadilan. Nilai- nilai tersebut merupakan nilai universal ajaran Islam yang bersifat eternal dan bisa diaplikasikan dalam pelbagai konteks, baik ruang, waktu dan perkembangan peradaban. ${ }^{31}$ Keyakinan akan universalitas ajaran Islam adalah salah satu bagian penting dari teologi Islam, yakni"al-Islām șāliḥ li kulli zamān wa makān" (Islam dapat berlaku dan diberlakukan dalam semua dimensi waktu, tempat dan kondisi kemasyarakatan). Untuk hadis-hadis yang memiliki sebab khusus (asbab al wurud), konteks ini tetap dipertimbangkan dalam rangka menyarikan ide atau menggali nilai dasarnya. Dalam konteks pemahaman hadis ini, kaidah "al-ibratu bi 'umūm al-lafụ lā bi khuṣūṣ al-sabab" lebih dikedepankan. Konteks turunnya hadis bersifat partikular, sementara nilai dasarnya bersifat universal.

\section{Etika Sosial-humanistik}

Pemahaman hadis harus berlandaskan pada prinsip etis sosial humanistik. Yaitu prinsip pergaulan yang mengedepankan hubungan yang bersifat simbiosis

${ }^{30}$ Noorhidayati, "Paradigma”, h. 107.

31 Ibid., h. 67-75. 
mutualisme, saling menguntungkan, saling menghormati, tidak berprasangka buruk, dan menghargai perbedaan. Baik perbedaan jenis kelamin, ras maupun agama. Berpegang pada prinsip ini, maka pemahaman hadis tidak terjebak pada dua kutub yang ekstrem, yaitu terlalu rigid atau terlalu bebas. Islam memberikan ruang yang luas bagi setiap orang agar mengamalkan toleransi dan menghargai kebebasan.

Dalam memahami hadis-hadis tentang relasi manusia, harus mengacu pada nilai-nilai humanistik, dimana hubungan antara manusia, laki-laki dan perempuan baik internal agama maupun antar agama lain, harus didasarkan pada penghargaan dan penghormatan sisi manusiawi seseorang.

\section{E. Parameter Pemahaman Hadis-hadis Bidang Muamalah}

Untuk mewujudkan pemahaman hadis yang șālih li kulli zamān wa makān, maka kriteria yang bisa dijadikan parameter adalah unsur-unsur dalam Hak Asasi Manusia (al-ḥuqūq al-insāniyyah al-asāsiyyah). Hak asasi ini merupakan pengejawantahan dari prinsip-prinsip universal dalam ajaran Islam. Pemahaman hadis dianggap relevan (salih) jika tidak bertentangan dengan prinsip tersebut. Pelanggaran terhadap salah satu prinsip ini merupakan bentuk pelanggaran hak asasi dan dianggap diskriminatif. Oleh karena itu, sikap anti diskriminatif menjadi salah satu kriteria yang menjadi acuan dalam memahami hadis Nabi.

Dalam konteks hadis-hadis muamalah tentang relasi antar umat beragama dan relasi gender, ada dua sikap anti diskriminasi yang bisa diketengahkan yaitu anti diskriminasi agama dan anti diskriminasi gender. ${ }^{32}$

\section{Sikap Anti Diskriminasi Agama}

Kriteria anti diskriminasi agama sesungguhnya mengacu kepada prinsip kesetaraan kaum beriman seperti disinyalir dalam QS. al-Māidah [5]: 69. Ayat tersebut mengakui secara eksistensial kaum non-Muslim, dan oleh karenanya umat Islam harus membangun hubungan yang harmoni dengan mereka dan tidak berlaku diskriminatif.

\footnotetext{
32 Noorhidayati, “Paradigma” h. 130.
} 
Untuk menghindari sikap diskriminatif terhadap penganut agama lain, maka menurut Sayid Sabiq, hubungan antara Muslim dengan non-Muslim menurut Islam dibangun atas dasar prinsip-prinsip sebagai berikut: ta'āruf (perkenalan); ta'āwun (tolong-menolong), tabādul al-mașāliḥ (win-win relationship) musālamah (perdamaian); mu'āsharah al-jamīlah (pergaulan mesra); mu'āmalah bi 'l-husnā (bermasyarakat/berinteraksi secara baik). ${ }^{33}$

Prinsip di atas disarikan dari ajaran Nabi dalam berinteraksi dengan umat lain, seperti dijelaskan sebagai berikut: 1) tidak boleh membalas perlakuan tidak baik secara berlebihan sebagaimana terlihat teguran Nabi terhadap Aisyah dalam menjawab salam dari orang Yahudi,34 2) kebolehan melakukan penyerangan dalam rangka membela diri, harta dan agama, ${ }^{35}$ dan masih banyak lagi.

Paparan di atas menegaskan dua hal: pertama, bahwa Islam menghormati dan menghargai setiap manusia, dan kedua, ajaran Islam tidak mengandung unsur diskriminatif.

\section{Sikap Anti Diskriminasi Gender}

Kriteria anti diskriminasi gender sesungguhnya merujuk kepada prinsipprinsip kesetaraan gender (Gender Equality). Terdapat beberapa variabel yang bisa digunakan sebagai standar dalam menganalisa prinsip-prinsip kesetaraan gender dalam al-Qur'an. Variabel yanag dimaksud adalah: a) laki-laki dan perempuan sama-sama sebagai hamba Allah; b) laki-laki dan perempuan samasama sebagai khalifah di bumi; c) laki-laki dan perempuan menerima perjanjian primordial; d) Adam dan Hawa terlibat secara aktif dalam drama kosmis; e) laki dan perempuan berpotensi meraih prestasi. ${ }^{36}$

${ }^{33}$ Sabiq, Fiqh al-Sunnah , (Beirut: Dār al-Fikr, 1983), jilid III, h. 13; Noorhidayati, Hadis-hadis Diskriminatif,...h. 142 dan Noorhidayati, "Paradigma..." h. 133; bandingkan dengan Abd al-Mu'thi Muhammad Bayumi, al-Islām fi al-Qarn al-hāāī wa al-'Isyrīn Ru'yah 'Așriyyah li al-Islām (Mesir: Nahḍah MiṢr, 2010), h. 209-211.

${ }^{34}$ al-Bukhārī, al-Jāmi' al-Ṣahīh, Juz 5, h. 2350.

${ }^{35} \mathrm{Abū}$ al-Husain Muslim bin al-Hajjāj bin Muslim al-Qusyairī, al-Jāmi' al-Ṣahịh al-Musammā Sahīḥ Muslim (Beirut: Dār al-Afāq al-Jadīdah, tt), Juz , h. 871. Lihat Ahmad bin Syu'aib Abū 'Abd alRaḥman al-Nasā'ì, al-Sunan al-Nasāî al-Kubrā (Beirut: Dār al-Kutub al-'Ilmiyyah, 1991), Juz 2, h. 30^ dan 310.

${ }^{36}$ Nasarudin Umar, Argumen Kesetaraan Gender Perspektif al-Qur'an (Jakarta: Paramadina, 2001), h. 247-264. 
Prinsip kesetaraan gender di atas dipertegas kembali oleh hadis- hadis Nabi, bahwa: a) ada persamaan antara laki-laki dan perempuan dari sisi substansi dan proses penciptaan. Secara substansi laki-laki dan perempuan sama-sam diciptakan dari unsur yang sama yaitu nutfah laki-laki dan nutfah perempuan. ${ }^{37}$ Keduanya juga melalui proses tahapan dan waktu penciptaan yang sama. ${ }^{38}$ b) persamaan hak dan kewajiban antara laki-laki dan perempuan; sama-sama berhak mendapat pahala dan balasan surga atas amal dan ibadah yang dilakukan. 39

Berdasarkan prinsip kesetaraan gender yang diusung oleh al-Qur'an dan hadis tersebut memberikan ketegasan bahwa prestasi individual, baik dalam bidang spiritual maupun urusan karier profesional tidak dimonopoli oleh satu jenis kelamin saja. Oleh karena itu pemahaman hadis yang humanis harus tetap dilakukan. Dalam memahami hadis-hadis yang bersifat kritis-disosiatif, harus tunduk di bawah sinaran prinsip universal dan hadis-hadis yang apresiatifasosiatif lainnya.

Secara metodologis, pendekatan antroposentris-kontekstual ini menempuh gerak double movement sebagaimana diajukan Fazlur Rahman. Langkah pertama mencari konteks awal hadis, kemudian disarikan ide dasar (nilai fundamental) dan nilai-nilai etis humanistis. Nilai-nilai inilah yang menjadi pertimbangan pemahaman dan penerapan hadis dalam konteks kekinian.

Adapun langkah prosedur pemahaman hadis bisa diilustrasikan sebagai berikut: langkah pertama adalah mengemukakan konteks dan realitas yang sedang terjadi pada saat ini. Langkah ini penting sebagai pra pemahaman kita bahwa dalam kehidupan masyarakat saat ini terdapat permasalahanpermasalahan yang perlu dicarikan solusi dan dasarnya dalam ajaran agama. Langkah kedua adalah menelusuri hadis-hadis secara tematik kepada kitab induk (al-mașadir al-așliyyah), untuk dipetakan kemungkinan adanya per-

${ }^{37}$ Ahmad bin hanbal, Musnad al-Imām Ahmad bin hanbal,' Musnad al-Mukthirīn min alȘahābah, Musnad Abd Allāh bin Mas'ūd (Beirūt: Muassasah al-Risālah, 1995), juz. VII, h. 437, hadis no. 4438. Lihat, Noorhidayati, "Menalar", h. 138-140.

${ }^{38}$ Muslim, Șahīh Muslim, Kitāb al-Qadr, Bāb Kaifiyyah Khalq Ādamī fī Bați Ummihī wa Kitāb Rizqihī wa Ajalihì, juz. VIII, h. 45, hadis no. 6898. Lihat Noorhidayati, "Menalar", h. 142-145.

${ }^{39}$ al-Bukhārī, șahi\}>h al-Bukhārī, Kitāb al-Zakāh, Bāb Man Amara Khādimahu bi al-Ṣadaqah, juz. II, h. 112, hadis no. 1425, dan Ahmad ibn hanbal, Musnad Ahmad, Kitāb Musnad al-'Asyrah alMubasysyirīn bi al-Jannah, Bāb Hadīs Abd al-Raḥmān bin ‘Auf al-Żuhrī, juz. III, h. 199, hadis no. 1661. Lihat Noorhidayati, "Menalar" h. 162 -164. 
bedaan dan kontradiksi secara tekstual dan dikorelasikan dengan dalil-dalil lain yang terkait.40 Jika penelusuran tematik ini menemukan data kontradiksi antar hadis, maka langkah metodologis penyelesaian hadis mukhtalif perlu dilakukan lebih dulu. ${ }^{41}$ Ketiga melacak konteks yang mengitari kemunculan hadis (baik mikro maupun makro) dan keempat adalah melakukan pemahaman atas kandungan hadis dalam rangka mencari tujuan atau pesan yang terkandung dalam teks. Pada tahap ini, parameter dan kriteria pemahaman hadis sebagaimana diuraikan di atas menjadi acuan. Selanjutnya, langkah kelima adalah melakukan kontekstualisasi pemahaman untuk dilihat sisi kesesuaian ajaran (șalih) yang dikandung oleh teks hadis dengan konteks kekinian.

Sebagai contoh hadis tentang kewajiban istri memenuhi hasrat seksual suami, kapan dan dimanapun dikehendaki. ${ }^{42}$ Hadis ini, di kalangan Muslim tertentu, khususnya suami sering dijadikan alat untuk menekan dan memaksa istri untuk melayani kebutuhan biologis suami. Ancaman laknat dalam hadis memberikan ketegasan bahwa pelayanan seksual ini adalah mutlak tanpa mempertimbangkan keadaan dan kondisi istri. Banyak kasus kekerasan dalam rumah tangga (KDRT) yang berawal dari pemahaman terhadap hadis ini. Untuk itu penelusuran terhadap teks redaksional hadis diperlukan. Setelah ditemukan riwayat lengkap hadis dan variasi redaksinya, dilakukan analisis konteks mikro (asbab al- wurud) maupun makro (setting sosial) dan analisis kebahasaan baik sisi semantik maupun hermeneutiknya.

Walaupun hadis ini șahịh, namun pembacaannya secara tekstualis mengesankan pemahaman yang bias gender yang cenderung melecehkan perempuan karena menjadikan perempuan sebagai objek pemuasan nafsu seks. Yang demikian ini tentu bertentangan dengan prinsip dasar ajaran Islam yang menghargai dan menghormati perempuan sebagaimana laki-laki. Oleh karena itu, hadis ini lebih tepat dipahami secara kontekstual dengan beberapa analisis. Pertama, mengingat masalah hubungan suami istri ini bukan hanya bersifat jasmaniyah, maka aspek psikologis harus menjadi pertimbangan. Kesiapan

\footnotetext{
${ }^{40}$ Dalil-dalil lain yang dimaksud adalah dalil al-Quran, dan hadis-hadis yang berkaitan dengan tema yang dibahas.

${ }^{41}$ Terkait dengan langkah metodologis penyelesaian hadis-hadis mukhtalif, baca buku Noorhidayati, Ilmu Mukhtalifal- Hadis Kajian Metodologis dan Praktis (Yogyakarta: Lentera, 2016), h. 99-101.

42Muslim, Sạhịh Muslim, Kitāb al-Nikāh, juz IV, h. 157, hadis no. 3614.
} 
mental kedua belah pihak lebih diutamakan karena bisa menjamin terwujudnya kebahagiaan lahir dan batin. Kedua, kata la'nah yang biasa dipahami sebagai "murka" yang bersifat transendental, perlu diarahkan pada makna yang bersifat sosiologis, bahwa tidak terpenuhinya kebutuhan seksual suami-istri atau salah satunya akan berdampak pada ketidakbaikan dan ketidakharmonisan yang berujung pada ketidakbahagiaan. Pendekatan kontekstual semacam ini menempatkan suami dan istri secara setara dan menjadikan bahwa kebutuhan seksual bukan hanya hak suami tapi merupakan kebutuhan pasangan tersebut dan pemenuhannya harus berdasarkan kesiapan dan kesepakatan berdua. Pemahaman semacam ini, dianggap lebih relevan (șālih) untuk konteks kekinian.

Demikian juga dengan hadis-hadis tentang relasi antar umat beragama, seperti hadis tentang perintah membunuh orang Yahudi dan Nasrani, ${ }^{43}$ atau siapa pun sampai mau mengucapkan kalimat "Lā ilāha illa Allāh". ${ }^{44}$ Bunyi redaksional hadis ini menunjukkan perintah untuk membunuh (Yahudi dan Nasrani atau (orang Non-Muslim) kapan dan dimanapun tanpa alasan sekalipun. Kelompok-kelompok tertentu yang memahami secara tekstualis menjadikan hadis ini sebagai dasar dan justifikasi untuk memerangi umat NonMuslim. Namun, jika pemahamannya didasarkan pada nilai-nilai kemanusiaan, bahwa orang non-Muslim pun punya hak untuk hidup dan beragama yang harus dihargai, maka hadis-hadis ini bisa ditempatkan secara proporsional.

Berdasarkan uraian di atas, bisa dinyatakan beberapa karakteristik paradigma pemahaman hadis yang antroposentris. Dari sisi prosedur pengkajian, pemahaman hadis antroposentris tidak mensyaratkan uji otentisitas sebelum pemahaman. Hal ini mengingat nilai ke-șăliḥ-an (kesesuaian) hadis dengan kebutuhan dan perkembangan zaman lebih diutamakan daripada ke- șahịh-an hadis, karena hadis yang șahịh kalau tidak dipahamai dengan pendekatan yang tepat belum tentu șālih. Dari sisi metode dan pendekatan, pemahaman hadis dengan paradigma ini menggunakan metode tematik dengan pendekatan kontekstual. Metode tematik menjadi suatu keniscayaan untuk mengatasi problem kontradiksi tekstualita hadis, dan pendekatan kontekstual karena lebih mengedepankan makna substantif dari sunnah Nabi. Dari sisi otoritas, paradigma ini bersifat subjektif. Yakni memberi kewenangan yang luas kepada

\footnotetext{
${ }^{43}$ al-Bukhārī, al-Jāmi' al-Ṣāhịh , Juz 3, h. 1274.

${ }^{44}$ Ibid, Juz 1, h. 153.
} 
manusia untuk mengambil nilai-nilai positif sesuai dengan kepentingan dan kebutuhan.

Demikianlah uraian paradigmatik yang bisa diusung untuk menjadi alternatif dalam memahami hadis-hadis Nabi, khususnya hadis-hadis bidang mu'amalah. Oleh karena itu, pada saat ini, pemahaman hadis-hadis tentang relasi antar umat beragama maupun relasi laki-laki dan perempuan sudah selayaknya tidak boleh bertentangan dengan semangat memperjuangkan hal-hak asasi manusia yang anti diskriminatif dalam berbagai aspek.

\section{F. Kesimpulan}

Hadis Nabi sebagai refleksi perkataan dan perbuatan Nabi harus dilihat dalam perspektif yang holistik. Memahami hadis Nabi perlu mempertimbangkan posisi dan peran Nabi serta bentuk kandungan hadis. Selain sebagai penyampai wahyu dan legislator, Nabi saw adalah manusia biasa yang hadir di tengah relasi sosial yang dinamis. Oleh karena itu, hadis tentang muamalah harus didekati dengan pola pemahaman yang lentur, luwes, fleksibel dan kontekstual.

Pembahasan dalam artikel ini menghasilkan temuan, sebagai berikut: Pertama, hadis muamalah merefleksikan konstruk relasi manusia, dan bisa berubah sesuai dengan perubahan dan perkembangan kehidupan sosial serta dinamika hubungan sosial yang fluktuatif. Oleh karena itu hadis-hadis ini bisa dipahami dengan menggunakan paradigma antroposentris dengan pendekatan kontekstual, yang berorientasi pada kebutuhan manusia dan menjadikannya sebagai subjek sekaligus objek dalam pemahaman. kedua, paradigma antroposentris ini dibangun berdasar dua argumen: a) refungsionalisasi hadis, memahami hadis harus bisa mengembalikan fungsinya sebagai media menemukan sunnah Nabi dan menghadirkannya kembali dalam konteks sekarang. b) reorientasi studi hadis. Kajian hadis tidak hanya berhenti pada uji otentisitas (maqbül dan mardūd) yang berorientasi pada aspek kualitas (șaḥịh, hasan dan daîff), tapi juga diarahkan pada aspek pengamalan ajaran yang dikandung (ma'mūl bih atau gair ma'mūl bih) yang menekankan sisi relevansi (șāliḥ). Pemahaman antroposentris ini berpegang pada prinsip dan nilai-nilai universal yang terkandung dalam teks hadis serta etika sosial humanistik yang menjunjung tinggi nilai kemanusiaan yang berkeadilan, setara dan toleran tanpa diskriminasi dalam berbagai bidang.] 


\section{DAFTAR PUSTAKA}

Abdullah, M. Amin, Studi Agama: Normativitas dan Historisitas?. Yogyakarta: Pustaka Pelajar, 1996.

Abdurrahman, M, "Menelusuri Paradigma Ulama dalam Menentukan Kualitas Hadis", dalam al-Jami'ah Journal of Islamic Studies, Vol. 41, No. 2, 2003/1424, 417.

Adlabī, Șalāh al-Dīn al-, Manhaj Naqd al-Matn 'inda 'Ulamā'al-Hadīth al-Nabawī, Beirut: Dār al-Āfaq al-Jadīdah, 1983.

Abidin, Ahmad Zainal, Madzhab Objektif dan Subjektif dalam Hermeneutika alQur'an Kontemporer. Tulungagung: STAIN Tulungagung Press, 2008.

Ali, Hadis Versus Sains Memahami Hadis-hadis Musykil, Yogyakarta: Teras, 2008.

Ali, Nizar, Memahami Hadis Nabi: Metode dan Pendekatan, Yogyakarta: CESaD YPI al-Rahmah, 2001.

Arfa, Faisar Ananda, Wanita dalam Konsep Islam Modernis, Jakarta: Pustaka Firdaus, 2004.

Bayumi, Abd al-Mu'thi Muhammad, al-Islām fi al-Qarn al-hādī wa al-'Isyrīn Ru'yah 'Așriyyah li al-Islām. Mesir: Nahdhah Misr, 2010.

Brown, Daniel W, Menyoal Relevansi Sunnah Dalam Islam Modern . Bandung: Mizan, 2000.

al-Bukhari, Șahịḥ al-Bukhāri. I, Singapore: Sulaiman Ma'i, ttth.

Damīniy, Musfir 'Azm Allāh al-. Maqāyis Naqd Mutūn al-Sunnah. Riyād: t.p., 1984.

Esack, Farid, Qur'an, Liberation and Pluralism: An Islamic Perspective of Interreligious Solidarity against Oppresion. Oxford: Oneworld Publication, 1997.

Ghalib, Muhammad, Ahli Kitab: Makna dan Cakupannya, Jakarta: Paramadina, 1998.

Ghazali, Muhammad al-, Fiqh al-Sirah, terj. Abu Laila, dkk. Bandung: al-Ma'arif, 1985.

HAM, Musahadi, Evolusi Konsep Sunnah(Implikasinya pada Perkembangan Hukum Islam, Semarang: Aneka Ilmu bekerja sama dengan IAIN Walisongo Press, 2000. 
Hanafi, Hassan, Dialog Agama dan Revolusi. Jakarta: Pustaka Firdaus, 1991.

Hanafi, "Apa Arti Kiri Islam", dalam Kazuo Shimogaki, Kiri Islam antara Modernisme dan Postmodernisme Telaah Kritis Pemikiran Hassan Hanafi, (terj) M. Imam Aziz dan M. Jadul Maula. Yogyakarta: LKiS, 1994.

Hidayat, Komaruddin, Memahami Bahasa Agama, Sebuah Kajian Hermeneutika, Jakarta:Paramadina, 1996

Hitti, Philip K, History of the Arabs, London: The Macmillan Press, 1974.

Ilyas, Muhammad Azhar dan Hamim (ed.), Pengembangan Pemikiran Keislaman Muhammadiyah: Purifikasi dan Dinamisasi, Yogyakarta: Majis Tarjih dan Pengembangan Pemikiran Islam PP Muhammadiyah dan LPPI UMY, 2000.

Isma'il, Syuhudi, Hadis Nabi Yang Tekstual dan Kontekstual: Telaah Ma'anil Hadis Tentang Ajaran Islam Yang Universal, Temporal dan Lokal, Jakarta: Bulan Bintang, 1994.

Jawābiy, Muhammad Ṭāhir al-, Juhūd al-Muḥaddithīn fi Naqd Matn al-ḥadìth an-Nabāwiyasy-Syarïf, t.t.p.: Muassasah Abdul Karīm bin Abdillāh, t.th.

Jawziyyah, Ibn Qayyim al-, Zād al-Ma'ād, III, t.t.p.: Dār Ihyya al-Turath al-'Arabiy, t.th.

Mas'udi, Masdar F., Islam dan Hak-hak Reproduksi Perempuan, Bandung: Mizan, 1997.

Muslim, Șahịḥ Muslim I. t.tp: Dar al-Fikr, t.th.

Najwa, Nurun, "Rekonstruksi Pemahaman Hadis-hadis Perempuan." Disertasi. Yogyakarta: UIN Sunan Kalijaga, 2006.

Najwah, Nurun, "Telaah Kritis terhadap Hadis-hadis Misoginis", Esensia: Jurnal Ilmu-Ilmu Ushuluddin, Vol. 4, No. 2, Juli 2003.

Nasution, Adnan Buyung, "Hak Asasi Manusia dalam Masyarakat Islam dan Barat" dalam Natsir Tamara dan Elza Peldi Taher (ed.), Agama dan Dialog antar Peradaban, Jakarta: Paramadina, 1996.

Noorhidayati, Salamah, Hadis-hadis Diskriminatif terhadap Umat Beragama Lain: Pemahaman Hadis dengan Pendekatan Sosio-Historis, Tulungagung: STAIN Tulungagung Press, 2010. 
"Menalar Pandangan Hadis-hadis tentang Perempuan", Disertasi, Program Pascasarjana UIN Sunan Kalijaga, Yogyakarta, 2013.

"Paradigma pemahaman Hadis: Dari Kesahihan Menuju Kesalihan Hadis" Laporan Penelitian Individual, IAIN Tulungagung 2015.

- Ilmu Mukhtalif al-Hadis Kajian Metodologis dan Praktis. Yogyakarta: Lentera, 2016

Qarafi, Abu al-Abbas Ahmad ibn Idris al-, al-Furūq fi Anwā' al-Furūq, juz I, kaidah ke-36, Beirut: Dar al- Kutub al- Ilmiyyah, 1998.

Rahman, Fazlur, Membuka Pintu Ijtihad, terj. Anas Mahyuddin, Bandung: Pustaka, 1995.

Methodology in History, Karachi: Central Institute of Islamic Research, 1965.

Rayyah, Mahmūd Abū, Aḍwā 'alā al-Sunnah al-Muhammadiyyah aw Difā' al-Hadìth, Mesir: Dār al-Ma'ārif, t.th.

Rudliyana, Muhammad Dede, Perkembangan Pemikiran ulum al-Qur'an dari Klasik sampai Modern, Bandung: Pustaka Setia, 2003.

Sabiq, Sayid, Fiqh al-Sunnah , Beirut: dar al-Fikr, 1983.

Soemardi, Selo Soemardjan dan Soelaeman, Setangakai Bunga Sosiologi, Jakarta: Yayasan Badan Penerbit Fakultas Ekonomi Universitas Indonesia, 1964.

Suryadi, "Rekonstruksi Kritik Sanad dan Matan dalam Studi Hadis" dalam Esensia: Jurnal Ilmu-Ilmu Ushuluddin, Vol. 16, No. 2, Oktober 2015.

Suryadi, Hamim Ilyas \& (ed.), Wacana Studi Hadis Kontemporer, Yogyakarya: Tiara Wacana Yogya, 2002

Syalțut, Mahmud, al-Islām 'Aqīdah wa Sharī’ah, Kairo: Dār al-Qalam, 1966. al-Islām 'Aqīdah wa Sharīah. Beirut: Dar al- Fikr,1996.

Umar, Nasarudin. Argumen Kesetaraan Gender Perspektif al-Qur'an, Jakarta: Paramadina, 2001.

Watt, W. Montgomery, Muhammad Prophet and Statesman, London: Oxford University Press, 1996.

Wehr, Hans, A Dictionary of Modern Written Arabic, J. Milton Cowan (ed), London: Weisbaden Otto Harrassowitz, 1971. 